NBER WORKING PAPER SERIES

\title{
WHAT HAPPENS WHEN COUNTRIES PEG THEIR EXCHANGE RATES? (THE REAL SIDE OF MONETARY REFORMS)
}

\author{
Sergio Rebelo
}

\author{
Working Paper 6168 \\ http://www.nber.org/papers/w6168
NATIONAL BUREAU OF ECONOMIC RESEARCH 1050 Massachusetts Avenue
Cambridge, MA 02138
September 1997

I am grateful for conversations with Antonio P. Barbosa, V. V. Chari, Rudi Dornbusch, Scott Freeman, Assar Lindbeck, Marcus Miller, Torsten Persson, Pierre Sarte, Carlos Vegh, and seminar participants at numerous institutions. Financial support from the NBER's Olin Fellowship is gratefully acknowledged. The usual disclaimer applies. This paper is part of NBER's research programs in Economic Fluctuations and Growth and International Finance and Macroeconmoics. Any opinions expressed are those of the author and not those of the National Bureau of Economic Research.

(C) 1997 by Sergio Rebelo. All rights reserved. Short sections of text, not to exceed two paragraphs, may be quoted without explicit permission provided that full credit, including $(C)$ notice, is given to the source. 
Whan Happens When Countries Peg Their Exchange

Rates? (The Real Side of Monetary Reforms)

Sergio Rebelo

NBER Working Paper No. 6168

September 1997

JEL No. F41

Economic Fluctuations and Growth

and International Finance and Macroeconomics

ABSTRACT

There is a well-known set of empirical regularities that describe the experience of countries that peg their exchange rate as part of a macroeconomic adjustment program. Following the peg economies tend to experience an increase in GDP, a large expansion of production in the nontradable sector, a contraction in tradables production, a current account deterioration, an increase in the real wage, a reduction in unemployment, a sharp appreciation in the relative price of nontradables and a boom in the real estate market. This paper discusses how the changes in the expected behavior of fiscal policy that tend to be associated with the peg can contribute to explaining these facts.

Sergio Rebelo

Kellogg Graduate School of Management

Northwestern University

Evanston, IL 60208

and NBER

s-rebelo@nwu.edu 


\section{Introduction}

One of the most widely used policies to lower the rate of inflation is to peg the country's currency to that of a low inflation economy. Fixing the exchange rate is a clear signal that the Central Bank is determined to fight inflation; so determined that it is willing to forego the possibility of pursuing an independent monetary policy. Fixed exchange regimes have been adopted as part of macroeconomic stabilization programs by different countries in different epochs; by developed, politically stable economies in Europe and by developing, politically unstable countries in Latin America; by economies seeking to put an end to high rates of inflation and by countries trying to lower their already moderate rate of price increase; by economies with moderate government deficits and by countries with large fiscal imbalances. This diversity of circumstances makes it unlikely that there be any consistent pattern in the outcomes of these stabilization experiences. But these common patterns do exist, suggesting that similar economic mechanisms were at work in experiences as diverse as those of Chile in 1979, France in 1987, and Argentina in 1991.

There is a large literature on the effects of exchange rate based stabilization programs which focuses on the consequences of the changes in the rate of inflation that take place once the peg is adopted. ${ }^{1}$ Another branch of literature, associated with the work of Krugman (1979), stresses that a fixed exchange rate regime establishes important links between fiscal policy and monetary policy. Governments with large fiscal imbalances may have to resort to the monetization of the deficit, which leads to a gradual loss in reserves and, eventually, to a speculative attack on the currency. The lessons from this literature have been quickly absorbed by policy makers: governments strive to reduce their budget deficit after they fix the exchange rate to enhance the credibility of the peg. ${ }^{2}$

\footnotetext{
${ }^{1}$ Prominent examples of the recent literature include Rodriguez (1982), Calvo (1986), Helpman and Razin (1987), and Reinhart and Vegh (1992). The previous vintage of models includes contributions by Aukrust (1977), Bruno (1976), Corbo (1985), and Lindbeck (1979).

${ }^{2} \mathrm{~A}$ well-known exception is the Chilean 1970-71 experience under Salvador Allende,
} 
The objective of this paper is to isolate the consequences of the fiscal policy reforms that often accompany the decision to fix the exchange rate. We follow in the footsteps of Drazen and Helpman $(1988,1990)$ who also study the effects of anticipated changes in fiscal policy but focus on their impact on the dynamics of inflation.

Pegging the exchange rate tends to be associated with an increase in government efficiency in the present and in the future. This efficiency increase results from measures such as the reform of the tax system and the re-direction of government expenditures away from redistribution programs and "pork barrel" spending toward productive uses. Fiscal restraint measures such as these are essential components of a successful reform in light of the evidence analyzed by Kiguel and Livithan (1988).

There are other reasons, besides the fear of a speculative attack, for improvements in fiscal policy to go hand-in-hand with the adoption of a fixed exchange rate policy. By foregoing control of monetary policy governments loose the easiest way to finance spending increases which is to print money. ${ }^{3}$ Pegging the currency also forces the government to be more careful about debt management. In a fixed exchange rate regime it is no longer possible to wipe out the real value of government debt with a sudden burst of inflation (perhaps carefully timed to coincide with a worldwide shock). This makes the costs of government activity more transparent, giving elected officials better incentives to focus on improving the productivity of the private sector instead of playing redistribution games.

The model discussed in this paper is capable of generating the type of symptoms that actual economies experience upon fixing their exchange rates in response to plausible changes in fiscal policy. This suggests that the expectations about the behavior of fiscal policy-the real side of monetary reformsmay play an important role in shaping the effects of fixed exchange rate experiences.

In Rebelo and Vegh (1996) we explored a deterministic setting where the advent of reform was viewed as totally unanticipated and took place with

in which the peg was followed, in 1971 , by a $119 \%$ increase in M1 (Larrain and Meller (1991)). This monetary expansion was clearly incompatible with the peg, even taking into account that the demand for domestic real balances might have expanded in response to an initial decline in expected inflation.

${ }^{3}$ See Alesina (1989) and Alesina, Cohen and Roubini (1992) for evidence that budget deficits and money growth tend to increase in election years in several OECD democracies. 
the economy at the pre-reform steady state. In contrast this paper explores a stochastic environment in which agents take into account the possibility that a reform will be enacted. The fiscal experiments studied here are much more complex than the simple permanent fiscal contraction studied in Rebelo and Vegh (1996). In the scenarios that we explore government expenditures keep expanding while reform is postponed and are stabilized once reform is enacted. In these settings there is no simple relation between current public spending and the level of output; expectations about the path of fiscal policy play a key role in determining the effects of fiscal policy on the economy.

The next section of the paper reviews the empirical regularities that characterize the adoption of a fixed exchange rate regime as part of a macroeconomic adjustment program. ${ }^{4}$ Section 3 describes the basic model used in the analysis. Section 4 studies the effects of fiscal reforms together with those associated with pegging the exchange rate. Section 5 describes some avenues for introducing imperfect credibility into the analysis, discusses directions for empirical work and provides some conclusions.

\section{The Empirical Regularities}

The common features of several macroeconomic stabilization programs in "chronic inflation" countries which used the exchange rate as a nominal anchor have been recently summarized in Vegh (1992) and Rebelo and Vegh (1995). ${ }^{5}$ These stabilization experiences suggest that after fixing the ex-

\footnotetext{
${ }^{4}$ These experiences are markedly distinct from the effects of devaluation in a country that has been on a fixed exchange regime. See Gottfries (1991) for a discussion of sporadic devaluations.

${ }^{5}$ There is a voluminous literature on this topic. Froot and Rogoff (1992) discuss various aspects of the economic performance of countries in the EMU. Giovannini (1991) analyses the French and Italian experience since the 1979. Bacchetta (1994a,b) discusses the Spanish case. Bover (1992) describes the evolution of the real estate market in Spain, while Bover and Estrada (1994) document the behavior of Spanish durable consumption and house purchases. Rebelo (1993) summarizes the evolution of the main macroeconomic variables for Portugal. Sturzenegger (1991) provides a detailed description of the $1973 \mathrm{peg}$ in Argentina, while Larrain and Meller (1991) describes the macroeconomic adjustment program implemented by Allende's Unidad Popular. Uribe (1993) and Erceg and Levin (1994) provide theory and evidence for the Argentinean experience since 1991. Copelman (1994) discusses the role of credit in fueling the consumption booms of Mexico, Chile and Israel. Ades, Kiguel and Liviathan (1993) compare the experiences of three European
} 
change rate the economy tends to experience the following symptoms:

1. There is an economic expansion: consumption rises, the real wage increases, the rate of unemployment falls, there is often a boom in the real estate market. Investment increases in many experiences, but not as strongly or as consistently as consumption.

2. The relative price of non-tradables increases rapidly, slowing down the decline in the rate of inflation.

3. The current account and the trade balance deteriorate.

4. Production in the tradables sector often falls relative to trend.

5. There is a large fiscal adjustment in successful or temporarily successful programs.

6. The initial expansion in economic activity tends to be followed by a slowdown.

The appreciation in the relative price of non-tradables is the fact that has attracted the most attention in the literature; this relative price seems to "jump" after the peg is in place.

Facts (2), (3) and (4) are often viewed as warning signals that the exchange rate policy is not working: inflation is converging slowly, and the expansion seems to be driven by a consumption binge financed by foreign borrowing. The rise in wages is often viewed as artificial, as caused by the unions, by the government's hiring and expenditure policy, by the large inflows of foreign capital, or by the nominal rigidities in the system. The contraction in the tradables sector and the competitiveness loss associated with the rise in the real wage creates the impression that the policy is not sustainable. The expansion in the non-tradables sector is often attributed to the fact that this sector is protected from foreign competition and can hence raise its prices to compensate the rise in wages. The view that these unintended effects of the peg are undesirable has often led economists to advocate the use of price and wage controls. This type of controls was once

countries, Denmark, Ireland and France, with those of Israel and of several Latin American countries. Another set of relevant experiences is described in Sargent's (1982) classic paper on hyperinflation, which pertains to countries re-entering the gold standard. 
used so pervasively that a name was coined for adjustment programs that incorporated them: "heterodox reforms".

When the expansion that initially follows the peg turns into a recession the government is criticized for not having paid attention to the warning signals. In some experiences the onset of the recession coincides with an adverse shock, such as an adverse movement in terms of trade or a bad agricultural year, whose effects seem to be greatly amplified by the economy. The fixed exchange rate regime is often abandoned at this point. The economy tends to recover slowly, while the government often increases public expenditure in an effort to speed up the recovery (perhaps in time to win the next elections). The reduction in the government deficit that usually takes place in the initial stages of reform tends to be reversed at this point. ${ }^{6}$

From the standpoint of a model with flexible prices it is extremely surprising that this chain of events can be triggered by the decision to fix the exchange rate. In this class of models the only effects of a peg are associated with the reduction in transactions costs brought forth by the decline in inflation. If these shoe leather costs are small, the peg is, to a first approximation, irrelevant for the behavior of real variables.

In models with nominal rigidities pegging the exchange rate can produce real effects. However, when the peg is credible disinflation takes place quickly and painlessly even in models with nominal contracts. ${ }^{7}$ The effects of nominal rigidities in wages and prices are discussed in Rebelo and Vegh (1995). In isolation these nominal rigidities generate counterfactual scenarios. Nominal wage rigidity leads to a rise in the real wage above its equilibrium value once the rate of inflation declines as a result of the peg. This real wage rise should lead to a recession not an expansion; unemployment should rise, and output and investment should fall. ${ }^{8}$ Nominal price rigidities imply that the price of

\footnotetext{
${ }^{6}$ This U-shaped behavior of the deficit is documented by Kiguel and Liviathan (1988) for the three Argentinean exchange-rate-based stabilizations of 1959-62, 1967-70, and 197981.

${ }^{7} \mathrm{See}$, for instance, Backus and Driffil (1987), Fisher (1986), Taylor (1983), Vegh (1992), and Miller and Sutherland (1993).

${ }^{8}$ The point that nominal stickiness combined with imperfect credibility leads to a recession when the peg is adopted is made by Fischer (1988), in the context of a modified version of the Mundell-Fleming model, and by Miller and Sutherland (1993) in models with overlapping contracts. Calvo and Vegh (1993) discuss an economy with nominal price rigidities in which disinflation leads to an expansion. But in their economy the production of tradables is exogenous, while non-tradables operate under Calvo (1983)-type
} 
non-tradables is above its equilibrium value and thus have a counterfactual implication: there should be a recession in the non-tradable sector. Models with nominal rigidities can nevertheless produce realistic scenarios when the effects of these rigidities are combined with the supply side effects of a large disinflation. Still, there are some problems with models based on nominal rigidities. These rigidities should be important for periods no longer than a year or two; but the effects that we described usually persist for longer periods of time. As Froot and Rogoff (1992) have stressed, it is difficult to attribute the ongoing increase in the real wage to nominal rigidities. If the real wage was too high in the first period because expected inflation was higher than realized inflation this problem should be corrected in the second period. A sustained increase in the real wage requires that the difference between expected and realized inflation increase systematically over time.

Finally, if nominal rigidities were responsible for the events that we described one would expect agents to adopt simple forms of indexation. The effects of nominal rigidities could be dramatically reduced if: (i) nominal contracts were renegotiated once the peg is in place; and (ii) the new contracts were indexed to the tradables inflation. In practice, condition (i) is often satisfied in high inflation countries; governments tend to mandate the expiration of nominal wage contracts after pegging the currency to avoid unwarranted increases in the real wage rate.

\section{The Model}

Our point of departure will be the baseline small open economy model discussed in Rebelo and Vegh (1995). This model combines elements that are well known from the 1980's literature on intertemporal optimization in open economies and from the recent work on open economy real business cycle models. $^{9}$

staggered price setting, with production being demand determined.

${ }^{9}$ Contributions to the early literature on intertemporal optimization in open economies include Obstfeld (1981), Svensson and Razin (1983), Greenwood (1984), Razin (1984), Persson and Svensson (1985), Frenkel and Razin (1987), and Svensson (1984). The recent literature on dynamic general equilibrium models of open economies includes papers by Finn (1990), Cardia (1991), Stockman and Tesar (1990), Backus, Kehoe and Kydland (1992), and Baxter and Crucini (1993). 


\section{Preferences}

It is obvious that we need two sectors in the economy, tradables and nontradables, so the preferences of the representative agent have to be defined over sequences of consumption of these two goods $\left(C_{t}^{T}\right.$ and $\left.C_{t}^{N T}\right)$. Expected life-time utility is given by a two-good version of the momentary utility used in Greenwood, Hercowitz and Huffman (1988):

$$
\begin{aligned}
U & =E_{0} \sum_{t=0}^{\infty} \beta^{t} \frac{1}{1-1 / \sigma}\left\{\left[\left(C_{t}^{T}\right)^{\gamma}\left(C_{t}^{N T}\right)^{1-\gamma}-\psi\left(N_{t}\right)^{\nu}\right]^{1-1 / \sigma}-1\right\} . \\
\sigma & >0, \nu>1, \psi>0,0<\beta<1,0<\gamma<1
\end{aligned}
$$

The symbol $E_{0}$ denotes the expectation conditional on the information available at time zero. The stochastic elements of the model, described in Section 4, are the policy variables controlled by the government, which will take different values depending on whether a reform takes place or not.

The variable $N_{t}$ denotes the number of hours worked by the representative agent in period $t$. This momentary utility has the property that the optimal value of $N_{t}$ is solely a function of the real wage (net of taxes and deflated by the consumer price index). Thus an increase in wealth leaves the labor supply unaffected. This momentary utility has become a staple of small open economy models (see e.g. Mendoza (1991), Lundvik (1992), and Correia et al. (1995)) because it is consistent with the observed levels of consumption volatility and the countercyclical character of the trade balance.

\section{Technology}

We made a conservative assumption concerning the allocation of labor: labor is freely mobile between the two sectors. The $N_{t}$ units of labor supplied by each worker can be used to produce tradables or non-tradables:

$$
N_{t}^{T}+N_{t}^{N T}=N_{t} .
$$

Introducing costs to labor mobility or allowing labor to vary at the intensive or extensive margins, leads the model to predict a higher initial jump in the relative price of non-tradables in response to the reforms we will study.

The production of tradables requires labor and capital and takes place according to a Cobb-Douglas production function: 


$$
Y_{t}^{T}=A^{T}\left(N_{t}^{T}\right)^{\alpha} K_{t-1}^{1-\alpha} \quad 0<\alpha<1 .
$$

Non-tradables are assumed to be produced by combining labor with a specific factor such as land $(T)$.

$$
Y_{t}^{N T}=A^{N T}\left(N_{t}^{N T}\right)^{\eta} T^{1-\eta} \quad 0<\eta<1
$$

We assume that non-tradables are more labor intensive than tradables $(\eta>\alpha)$. This assumption is widely employed in the international trade literature, and is motivated by the fact that non-tradables are, for the most part, produced in the service sector. To economize on notation we abstract from technical progress. ${ }^{10}$

\section{Capital Accumulation Technology}

For convenience, we assume that the output of the tradable sector can be used for consumption or for investment $\left(I_{t}\right)$ but that the production of non-tradables is suitable only for consumption. Capital evolves according to the following law of motion:

$$
K_{t}=\phi\left(I_{t} / K_{t-1}\right) K_{t-1}+(1-\delta) K_{t-1}
$$

where $\delta$ denotes the rate of depreciation. The concave function $\phi($.$) reflects$ the presence of adjustment costs to investment. This function is assumed to be twice continuously differentiable and to have two properties that guarantee the absence of adjustment costs in the steady state: $\phi(\delta)=\delta$ and $\phi^{\prime}(\delta)=1$. This type of adjustment costs has been widely employed in open economy models to prevent investment from displaying excessive volatility.

\section{Transactions Technology}

\footnotetext{
${ }^{10}$ If we introduce technical progress in the model and assume that it increases productivity faster in the tradables sector, the relative price of non-tradables will increase at a constant rate in the steady state. This rate of growth is equal to $\left(g_{T} / g_{N T}\right)^{\eta-\alpha}$, where $g_{i}$ is the gross rate of labor-augmenting technical progress in sector $i$. This Balassa-Samuelson has been documented empirically by De Gregorio, Giovaninni and Krueger (1992) for OECD countries. This is, however, a low frequency movement that cannot rationalize the sharp increase in the relative price of non-tradables that we observe upon the inception of reforms.
} 
Money is used for transactions according to a specification in which holdings of real money balances expressed in terms of traded goods allow the agent to economize on the amount of resources devoted to transactions. We denote these resources by $S_{t}$ and assume that they are denominated in terms of tradable goods:

$$
S_{t}=Z^{S}\left(C_{t}+I_{t}\right) v\left(\frac{M_{t} / P_{t}^{T}}{C_{t}+I_{t}}\right)
$$

where $P_{t}^{T}$ is the nominal price of traded goods, $M_{t} / P_{t}^{T}$ represents real money balances, and $Z^{S}$ is a level parameter. Total consumption defined in units of the tradable good is given by $C_{t}=C_{t}^{T}+p_{t} C_{t}^{N T}$. We assume that the function $v($.$) has the following quadratic form:$

$$
v(X)=X^{2}-X+1 / 4,
$$

where $X_{t}=M_{t} /\left[P_{t}^{T}\left(C_{t}+I_{t}\right)\right]$ is the inverse of the velocity of circulation with respect to total expenditure. This transactions technology generates a simple demand for real balances which is homogenous of degree one in total expenditures:

$$
\frac{M_{t}}{P_{t}^{T}}=\left(C_{t}+I_{t}\right) \frac{1}{2}\left[1-\frac{R_{t}}{Z^{S}\left(1+R_{t}\right)}\right],
$$

where $R_{t}$ denotes the nominal interest rate.

The quadratic form assumed for $v($.$) ensures that transactions costs are$ zero when the nominal interest rate is zero. In this case the equilibrium coincides with that of an analogous real economy where transactions can be carried out costlessly without the use of money. We will study versions of this economy in which the nominal interest rate is zero to isolate the effects of fiscal policy from those of monetary policy.

\section{The Household's Problem}

To economize on notation, we assume that households operate directly the economy's technology and sell their production in the goods market. Hence, they face the following budget constraint:

$$
b_{t}+C_{t}^{T}+p_{t} C_{t}^{N T}+I_{t}+S_{t}+\frac{M_{t}}{P_{t}^{T}}+\omega_{t}
$$




$$
=b_{t-1}\left(1+r^{*}\right)+\frac{P_{t-1}^{T}}{P_{t}^{T}} \frac{M_{t-1}}{P_{t-1}^{T}}+\left(1-\tau_{t}\right) Y_{t}^{T}+p_{t}\left(1-\tau_{t}\right) Y_{t}^{N T}
$$

The government levies taxes on the production of both goods at rate $\tau_{t}$ as well as lump sum taxes $\left(\omega_{t}\right)$. The variable $p_{t}$ denotes the relative price of non-tradables in terms of tradables.

Households can borrow and lend in the international capital market at the exogenous real interest rate $r^{*}{ }^{11}$ The variable $b_{t}$ represents private net foreign asset holdings. As usual, in order for the constraint (8) to be meaningful, we need to rule out the possibility of Ponzi games:

$$
\lim _{t \rightarrow \infty} E_{0} \frac{b_{t}}{\left(1+r^{*}\right)^{t}}=0 \text {. }
$$

To guarantee that there exists a steady state with a constant level of $b_{t}$, we assume that $\beta=\left(1+r^{*}\right)^{-1}$. This restriction, which would hold in a world composed of economies such as this one, guarantees that access to the international capital market does not change the steady state growth rate of consumption. The household's problem then consists in maximizing expected lifetime utility, defined in (1), subject to the constraints (2)-(9).

\section{The Government Budget Constraint}

The government collects taxes on the production of both goods at rate $\tau_{t}$, as well as lump sum taxes $\left(\omega_{t}\right)$, buys tradables $\left(G_{t}^{T}\right)$ and non-tradables $\left(G_{t}^{N T}\right)$. Government net foreign asset holdings $\left(f_{t}\right)$ evolve according to:

$$
f_{t}=f_{t-1}\left(1+r^{*}\right)+\frac{M_{t}}{P_{t}^{T}}-\frac{P_{t-1}^{T}}{P_{t}^{T}} \frac{M_{t-1}}{P_{t-1}^{T}}+\tau_{t} Y_{t}^{T}+\tau_{t} p_{t} Y_{t}^{N T}+\omega_{t}-G_{t}^{T}-p_{t} G_{t}^{N T}
$$

The path for $f_{t}$ has to satisfy the government no-Ponzi game condition:

$$
\lim _{t \rightarrow \infty} E_{0} \frac{f_{t}}{\left(1+r^{*}\right)^{t}}=0
$$

\section{Monetary Policy}

\footnotetext{
${ }^{11}$ In allowing agents to borrow and lend freely in the international capital markets we ignore the possibility of bankruptcy. This possibility is likely to be quantitatively unimportant in the experiments considered here.
} 
We assume that the government controls the rate of devaluation, $\varepsilon_{t}$. The level of $M_{t}$ will be endogenously determined by the demand for money and by the requirement that the price of tradable goods be the same in the two countries: $P_{t}^{T}=e_{t} P^{T *}$, where $P^{T *}$ is the foreign price of tradable goods and $e_{t}$ is the exchange rate.

Equilibrium in the Goods Market

Equilibrium in the non-tradable goods market requires:

$$
Y_{t}^{N T}=C_{t}^{N T}+G_{t}^{N T}
$$

Using this equation and aggregating the private and public budget constraints, we obtain the equilibrium conditions for the tradable goods market:

$$
\begin{gathered}
Y_{t}^{T}=C_{t}^{T}+I_{t}+S_{t}+G_{t}^{T}+T B_{t} \\
a_{t}=\left(1+r^{*}\right) a_{t-1}+T B_{t} .
\end{gathered}
$$

Here $a_{t}=b_{t}+f_{t}$, represents the consolidated net asset holdings of the government and of the private sector. $T B_{t}$ is the economy's trade balance. The current account is given by $C A_{t}=r^{*} a_{t-1}+T B_{t}$. In the absence of shocks, this economy is always at a steady state where $T B=-r^{*} a$. Any level of $a$ is consistent with the steady state. Economies with high values of $a$ will be able to afford larger trade deficits in the steady state and hence enjoy greater consumption levels.

\section{Model Calibration and Computational Methods}

The model was solved numerically using the certainty equivalence approximations discussed in King et al. (1988). The baseline parameterization, described in Table 1, was borrowed from Rebelo and Vegh (1995). The basic effects that we stress are robust across a wide range of parameterizations. Each time period is meant to represent one quarter. This parameterization replicates some key features of the Argentine economy in the decade before the 1991 "convertibility act". This plan involved pegging the peso to the dollar and required that the monetary base be backed $100 \%$ by gold and foreign reserves. The parameterization entails a low elasticity of intertemporal substitution $(\sigma=0.2)$ and relatively high adjustment costs to ensure that the 
results reported do not hinge on a large response of the economy to changes in its intertemporal opportunities.

The Wealth Effect

Since wealth effects will be important in the policy experiments described below, it is useful to discuss briefly their impact. Figure 1 shows the outcome of a $10 \%$ increase in the level of net foreign assets. As discussed in Rebelo and Vegh (1995) this generates two effects: a Hicksian wealth effect and substitution effects associated with changes in relative prices. The economy responds to this increase in $a$ by raising the consumption of both goods. If the relative price of these goods did not change we would see the same proportional increase in both types of consumption. However, without a change in the relative price, the economy would continue to produce the same amount of non-tradables. Thus, the price of non-tradables has to rise and, in equilibrium, the consumption of tradables expands by more than the consumption of non-tradables. Since labor is diverted from tradables to non-tradables production, investment declines because the rate of return to capital in the tradables sector falls below $r^{*}$. The presence of adjustment costs in the investment process implies a gradual fall in the stock of capital toward a lower steady state level.

Figure 2 illustrates the mechanics of the wealth effect for a simplified version of the model that abstracts from physical capital. The economy's initial position is given by point $A$, which lies on the production possibilities frontier relating tradables to non-tradables. When all domestic labor is allocated to the production of non-tradables, tradables consumption is financed by running a constant trade deficit equal to $a r^{*}$ (in Figure $2 a$ is assumed to be positive). Point $B$ is the equilibrium correponding to a higher level of net foreign assets, $a^{\prime}>a$. If the relative price of non-tradables did not change the equilibrium value of $C^{T} / C^{N T}$ would remain the same. However, this is inconsistent with maximizing the value of production; in equilibrium $p$ has to rise.

\section{The Effects of Reforms}

We will adopt a minimalist description of government policy that has the essential elements of an economy in which a reform has to take place at some 
time in the future. There are two states of nature, reform and non-reform. The economy starts out in the non-reform state and transits to reform with probability $\pi$. To simplify, we assume that the reform is permanent so the reform state is absorbing. The Markov chain that describes the evolution of the state of the economy is, thus:

$$
\Pi=\left[\begin{array}{cc}
1-\pi & \pi \\
0 & 1
\end{array}\right]
$$

where non-reform corresponds to state 1 . We assume that there is a maximum time span $T$ during which the economy can be in non-reform. In the absence of lump sum taxes this would be necessary to guarantee that the government's no-Ponzi game condition is satisfied. If the economy is still in the non-reform state in period $T-1$, reform will occur in period $T$ with probability one. The probability that reform will take place in period $t$ is given by:

$$
\operatorname{Pr}(\text { Reform Takes Place at Time } t)=\left\{\begin{array}{c}
\pi(1-\pi)^{t-1} \text { if } 1 \leq t \leq T-1 \\
(1-\pi)^{T-1} \text { if } t=T \\
0 \text { if } t>T
\end{array},\right.
$$

while the probability that the economy will be in the reform state in period $t$ is:

$$
\operatorname{Pr}(\text { Economy is in Reform State at Time } t)=\left\{\begin{array}{c}
1-(1-\pi)^{t} \text { if } t<T \\
1 \text { if } t \geq T
\end{array} .\right.
$$

We will discuss three types of reform. In the first two cases we will abstract completely from monetary factors by assuming that the nominal interest rate is zero, both before and after the reform. When the nominal interest rate is zero there are no resources devoted to transactions $\left(S_{t}=0\right)$ and the economy is equivalent to one in which all transactions can be made costlessly without the use of money. This allow us to isolate the effects of fiscal policy. In all Figures used to depict the experiments described below we express the different variables as percentage deviations from the initial steady state. 


\subsection{A Stabilization of Government Spending}

Suppose that while the economy is in the non-reform state the output tax rate remains constant at $\tau$, but government expenditures in both tradables and nontradables increase at rate $g_{G}$ in every period. Once the reform takes place the level of public spending stabilizes. If reform takes place in period $n$ the path of government expenditures is given by:

$$
G_{t}=\left\{\begin{array}{c}
G\left(1+g_{G}\right)^{t} \text { if } t<n \\
G\left(1+g_{G}\right)^{n-1} \text { if } t \geq n
\end{array} .\right.
$$

The timing of the reform matters because postponing the reform increases the present value of taxes that needs to be collected to finance the additional government expenditures. To see this consider a stripped-down version of the government budget constraint in which we abstract from seignorage, from non-tradables expenditures and non-tradables production, and assume, for illustration purposes, that tradables production is constant and equal to $Y$. In the initial steady state the present value of lump sum taxes, $\Omega=\sum_{t=0}^{\infty} \frac{\omega_{t}}{\left(1+r^{\circ}\right)^{t}}$ is such that:

$$
f_{-1}+\frac{\tau Y}{r^{*}}+\frac{\Omega}{1+r^{*}}=\frac{G}{r^{*}} .
$$

Suppose that the reform takes place in period $n$. The present value of lump sum taxes necessary to satisfy the government budget constraint is given by:

$$
\begin{aligned}
f_{-1}+\frac{\tau Y}{r^{*}}+\frac{\Omega^{\prime}}{1+r^{*}} & =\frac{G}{r^{*}}+\frac{1}{1+r^{*}} \sum_{t=0}^{\infty} \frac{G_{t}-G}{\left(1+r^{*}\right)^{t}}, \\
G_{t} & =G\left(1+g_{G}\right)^{t} \quad t<n, \\
G_{t} & =G\left(1+g_{G}\right)^{n-1} t \geq n .
\end{aligned}
$$

It is clear that there is an increase in the present value of taxes from the government to the households, relative to the initial steady state: $\Omega^{\prime}>\Omega$.

One way to interpret this reform experiment is to think of the government as financing the increase in government expenditure that takes place in the non-reform state by issuing domestic debt. This debt is then retired, once reform occurs, through an increase in lump sum taxes. However, this is not 
the only possible interpretation since the timing of lump sum taxes is irrelevant: only their present value matters. For example, we can also think of the government as financing the expenditure increase by reducing its net foreign assets, or by increasing $\omega_{t}$ in every period in the amount of the expenditure increase.

To illustrate how expectations about government expenditures evolve over time consider a numerical example in which $g_{G}=2 \%, T=50$ and $\pi=$ 0.05 . Figure 3 shows four paths for the percentage deviation of government expenditures from its initial level which will be denoted by $\hat{G}_{t}=\log \left(G_{t} / G\right)$ and assumed to be identical for both tradables and on non-tradables public expenditures. The first path, $E_{0}\left(\hat{G}_{t}\right)$ is the expected value of $\hat{G}_{t}$ conditional on the information available at time zero. Since after $t=T=50$ the economy will be in the reform state with probability one, the expected path of government expenditures becomes a constant after that point.

The second path is $E_{10}\left(\hat{G}_{t}\right)$, which is the expected path for government expenditure at $t=10$ in the case in which the economy is in the non-reform state at $t=10$. The values taken by $\hat{G}_{t}$ up to period 10 have already been realized at this point. Since reform has not occurred, government expenditures have increased at rate $g_{G}$ during this period. The expected values of $\hat{G}_{t}$ from period 10 on have been updated taking into account that the reform has not taken place, so $E_{10}\left(\hat{G}_{t}\right)>E_{0}\left(\hat{G}_{t}\right)$ for all $t$. The third path shows $E_{19}\left(\hat{G}_{t}\right)$ for the case in which reform has not yet taken place in period 19.

The final graph in Figure 3 depicts $E_{20}\left(\hat{G}_{t}\right)$ for the case in which reform takes place in period $t=20$. Before this period expenditures increased at rate $g_{G}$, after this period they are expected to remain constant. Since there is no further uncertainty once reform takes place, the path for $E_{20}\left(\hat{G}_{t}\right)$ coincides with the actual realizations of $\hat{G}_{t}$.

The results of this experiment, for a simulation in which the reform occurs at $t=20$, are described in Figure 4 . In period zero the economy transits from a situation in which $\hat{G}_{t}$ is expected to be constant, to one in which its path is governed by the stochastic process described by (15). This has a large negative wealth effect associated with the expected increase in lump sum taxes necessary to finance government spending. Thus, there is a reduction of consumption of both tradables and non-tradables and a reallocation of labor to the tradables sector. This labor reallocation has two effects: (i) it produces a fall in the relative price of non-tradables; and (ii) it raises the productivity of capital in the tradable sector, which leads to an increase in 
investment. In the absence of adjustment costs there would be a large investment burst in period one so as to equate the real rate of return in the tradables sector to the world's real interest rate, $r^{*}$. The presence of adjustment costs smooths out the investment response. Consumption continues to fall in every period that the economy remains in the reform state because the present value of government expenditures keeps increasing. The relative price of non-tradables increases during the non-reform regime because the government keeps increasing its expenditures in non-tradables. If the public spending increase affected only the tradable component, $p$ would fall during the non-reform regime.

When the reform takes place in period 20 there is a drastic improvement in the expected path of government expenditures (compare the expected paths for $\hat{G}_{t}$ in periods 19 and 20 ). This generates a positive wealth effect that increases consumption, raises the relative price of nontradables, the real wage and the labor supply. Tradable output falls as labor is reallocated to non-tradables production. Investment falls in response to the decline in $N^{T}$. This is a robust feature of the model that survives when we change the elasticity of intertemporal substitution and the magnitude of the adjustment costs. The evolution of net foreign assets shows that the current account deteriorates as well. These effects agree with the facts described in section 2 with one exception: investment falls. 
Table 2

Sensitivity Analysis, Experiment 1

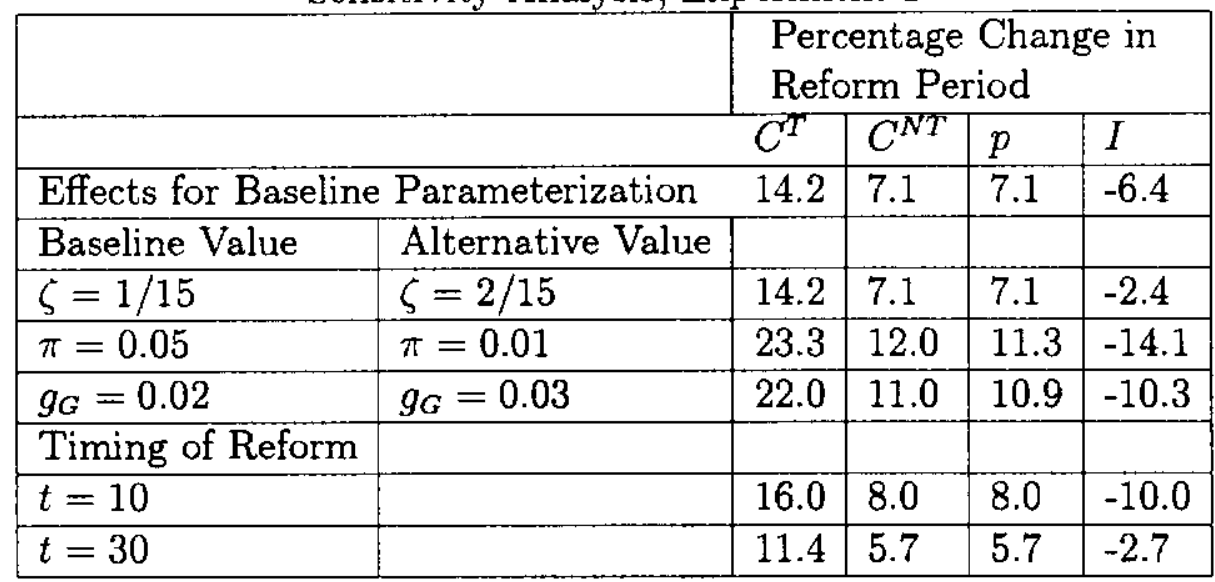

Table 2 reports the percentage change in consumption, investment and the real appreciation that take place at the time of reform for some different parameter configurations. Increasing the extent to which there are adjustment costs to investment $(\zeta)$ moderates the increase in capital that takes place in the first few periods and hence leads to a smaller fall in investment at the time of the reform. Reducing the probability of reform, $\pi$, raises the wealth effect associated with the reform, leading to larger movements in all the variables. Increasing the rate of expansion of government expenditure in the non-reform state also increases the wealth effect associated with the reform. Finally, Table 2 shows the effects of reforms that materialize at different points in time $(t=10$ and $t=30)$. The sooner the reform takes place the larger the wealth effect and the impact on all the variables.

One feature of this experiment is that government expenditures do not fall when the economy reforms, they simply stabilize. If the reform were associated with a fall in government expenditures we would observe the same qualitative features. However, the quantitative effects would be larger since the wealth effect would be even stronger.

We now turn to a more realistic version of this experiment in which the output tax rate increases when the reform takes place. 


\subsection{A Stabilization of Government Spending with a Rise in Output Taxes}

In this case government expenditures follow the same stochastic process as in experiment 1, but output taxes increase when the reform occurs. ${ }^{12}$ While the economy is in the non-reform state the tax rate remains constant at $\tau$. When the reform takes place at time $n$ there is a permanent increase in $\tau$ to the level $r\left(1+g_{\tau}\right)^{n-1}$. The path of taxes in an economy where reform happens in period $n$ is given by:

$$
\tau_{t}=\left\{\begin{array}{c}
\tau \text { if } t<n \\
\tau\left(1+g_{\tau}\right)^{n-1} \text { if } t \geq n
\end{array} .\right.
$$

This captures the idea that, since the level of public expenditures has risen throughout the non-reform period, the tax rate hike that has to be enacted upon reform is an increasing function of the number of periods that the economy spends in non-reform. This would clearly be the case if lump sum taxes were not available. ${ }^{13}$ Consider the same simplified government budget constrain that we studied before. Once again we abstract from seignorage, from non-tradables expenditures and non-tradables production, and assume, for illustration purposes, that tradables production is constant and equal to $Y$. In the absence of lump sum taxes the value of $\tau$ in the initial steady state has to be such that:

$$
f_{-1}+\frac{\tau Y}{r^{*}}=\frac{G}{r^{*}} .
$$

Consider now an economy in which the reform takes place in period $n$. The tax rate would have to increase to a level $\tau^{\prime}$ such that:

\footnotetext{
${ }^{12}$ In practice, the fiscal adjustments that take place upon reform can comprise not only increases in formal taxes but also more subtle forms of extracting revenue from the private sector. Examples include increases in the prices of publicly provided goods and services, forced lending to the government (a measure used in Argentina in 1987 (Fernandez (1991)), and even the nationalization of certain sectors of the economy. The privatization of public sector industries has been another commonly used source of revenue.

${ }^{13}$ In the absence of lump sum taxes the new tax rate would have to satisfy the government's intertemporal budget constraint. This would raise two problems. The first is conceptual: this tax adjustment procedure may generate multiple equilibria. The second problem is computational: one would have to solve for the tax rate associated with each possible reform date.
} 


$$
\begin{aligned}
\frac{\left(\tau^{\prime}-\tau\right) Y}{r^{*}\left(1+r^{*}\right)^{n-1}} & =\sum_{t=0}^{\infty} \frac{G_{t}-G}{\left(1+r^{*}\right)^{t}} \\
G_{t} & =G\left(1+g_{G}\right)^{t} t<n \\
G_{t} & =G\left(1+g_{G}\right)^{n-1} t \geq n
\end{aligned}
$$

The value of $\tau^{\prime}$ is an increasing function of $n$ for two reasons: (i) the present value of tax revenue that is necessary to satisfy the government's budget constraint increases with the number of periods the economy spends in non-reform; and (ii) the later the reform takes place the higher will have to be the tax increase even if we assume that the present value of additional expenditures does not increase with $n$, because the present value of the additional revenue declines with the number of periods that it takes to reform.

It is convenient to define $\hat{\tau}_{t}$ as the percentage deviations from the initial tax rate $\tau: \hat{\tau}_{t}=\log \left(\tau_{t} / \tau\right)$. Figure 5 shows the expected path of $\hat{\tau}_{t}$ at different points in time for the case where $g_{\tau}=0.01, T=50$, and $\pi=0.05$. The first graph shows $E_{0}\left(\hat{\tau}_{t}\right)$. Since in every period there is a probability $\pi$ that the reform will take place with the tax rate rising to $\tau\left(1+g_{\tau}\right)^{t}$, the expected value of $\tau_{t}$ is greater than $\tau$ in all future periods. The expected tax rate is particularly high after period $T$ simply because the economy will be in the reform state with probability 1 at this point. The second graph shows the expected path for taxes in period $10, E_{10}\left(\hat{\tau}_{t}\right)$, at a time where the economy is still in the non-reform state. The value of $\hat{\tau}_{t}$ is still zero in period 10 and, since reform might take place in the future, the expected value of $\hat{\tau}_{t}$ is above zero. The third graph, which shows the expected value of future taxes before the period in which the reform happens to take place, $E_{19}\left(\hat{\tau}_{t}\right)$ shares the same basic feature of $E_{10}\left(\hat{\tau}_{t}\right)$. Finally, the last graph shows the realizations of $\hat{\tau}_{t}$ for the case in which reform happens to take place in period 20. This coincides with $E_{20}\left(\hat{\tau}_{t}\right)$ since once the reform occurs all uncertainty is realized.

Figure 6 shows the effects of this experiment for a simulation in which reform happens to occur in period 20. The paths of the different variables are similar to those of Figure 4. An expansion continues to take place despite the sizable tax increase. This is in part a result of the wealth effect associated with the stabilization of spending. Also, the tax increase that takes place in period 20 avoided a much larger tax increase that would have to take place 
if the economy remained in the non-reform state.

Table 3

Sensitivity Analysis, Experiment 2

\begin{tabular}{|c|c|c|c|c|c|}
\hline & \multicolumn{4}{|c|}{$\begin{array}{l}\text { Percentage Change in } \\
\text { Reform Period }\end{array}$} \\
\hline & & $C^{T}$ & $C^{N T}$ & $p$ & $I$ \\
\hline \multicolumn{2}{|c|}{ Effects for Baseline Parameterization } & 13.6 & 6.4 & 7.2 & -14.7 \\
\hline Baseline Value & Alternative Value & & & & \\
\hline$\zeta=1 / 15$ & $\zeta=2 / 15$ & 13.7 & 6.4 & 7.2 & -7.0 \\
\hline$\pi=0.05$ & $\pi=0.01$ & 24.4 & 12.1 & 12.2 & -23.5 \\
\hline$g_{\tau}=0.01$ & $g_{\tau}=0.02$ & 12.7 & 5.5 & 7.2 & -22.8 \\
\hline \multicolumn{6}{|l|}{ Timing of Reform } \\
\hline$t=10$ & & 16.2 & 7.9 & 8.3 & -12.7 \\
\hline$t=30$ & & 10.1 & 4.4 & 5.7 & -15.8 \\
\hline
\end{tabular}

Table 3 reports the effects of altering various features of the experiment on the change in the key variables at the time of the reform. Variations in the timing of the reform, in the probability of reform and in the adjustment costs to investment have consequences that are similar to those examined in our first experiment. Table 3 also reports the consequences of raising $g_{\tau}$ to 0.02 . This is the rate of tax increase such that the present value of expenditures is roughly equal to the present value of government revenue, for the case in which the reform materializes at $t=20{ }^{14}$ The effects on consumption and on the change on $p$ are only slightly lower. In contrast investment declines even further than in the baseline case as a result of the higher tax rates.

\subsection{Incorporating the Effects of Disinflation}

We now incorporate the effects of disinflation in experiment 2. First, we modify the initial steady state in the economy by assuming that the rate of devaluation is $46 \%$. We then study the effects of a $100 \%$ reduction in the rate of devaluation coupled with the fiscal policy reforms discussed in the previous experiment.

\footnotetext{
${ }^{14}$ We adopted $g_{\tau}=0.01$ as our baseline value since in our third experiment the government will also collect revenue from the inflation tax.
} 
The decline in the rate of devaluation reduces the nominal interest rate and the cost of transacting. There is a wealth effect associated with the decline in resources devoted to transactions that increases the magnitude of the consumption boom. There is also an increase in the real return to investment net of transactions costs. This effect is strong enough to generate an investment boom that takes place in period 20 , but also changes the level of capital stock associated with the new steady state. In the two previous experiments the new steady state capital stock is lower than its level in period zero because there is a permanent decline in $N^{T}$. The reduction in transaction costs associated with disinflation is, in this case, strong enough to generate an increase in the steady state capital stock.

The consequences of changing some aspects of this experiment, reported in Table 3, are similar to those discussed before.

Table 4

Sensitivity Analysis, Experiment 3

\begin{tabular}{|c|c|c|c|c|c|}
\hline & \multicolumn{4}{|c|}{$\begin{array}{l}\text { Percentage Change in } \\
\text { Reform Period }\end{array}$} \\
\hline & & $C^{T}$ & $C^{N T}$ & $p$ & $I$ \\
\hline Effects for Baselin & Parameterization & 24.6 & 14.5 & 10.1 & 51.0 \\
\hline Baseline Value & Alternative Value & & & & \\
\hline$\zeta=1 / 15$ & $\zeta=2 / 15$ & 24.5 & 14.4 & 10.1 & 32.7 \\
\hline$\pi=0.05$ & $\pi=0.01$ & 41.5 & 24.0 & 17.5 & 27.2 \\
\hline Timing of Reform & & & & & \\
\hline$t=10$ & & 28.2 & 16.7 & 11.5 & 51.5 \\
\hline$t=30$ & & 19.3 & 11.3 & 8.0 & 53.0 \\
\hline
\end{tabular}

\subsection{Summary}

All three experiments were successful in reproducing the major features of exchange rate based stabilization. The main difference across the three experiments is in the behavior of investment. Recall that investment tends to rise with the stabilization but that its behavior is not nearly as consistent across different experiences as that of consumption. Investment declines in both the first and the second experiment. When we combined the effects of fiscal policy with those of disinflation, in our third experiment, we obtained an unambiguous rise in investment. 
The most puzzling feature of exchange rate based stabilization is the large magnitude of the consumption boom and of the appreciation in the real exchange rate. Rebelo and Vegh (1995) show that it is difficult to explain these large effects as being solely the result of the disinflation. One significant advantage of the fiscal channel that we described is that it allows the model to generate larger consumption booms and real exchange rate appreciations.

\section{Conclusion}

Countries that adopt a fixed exchange regime in the context of a macroeconomic adjustment program tend to implement fiscal policy reforms that improve the expected path of fiscal variables from the standpoint of private agents. This paper attempts to isolate the importance of these fiscal reforms that tend to go hand-in-hand with an exchange rate peg. The model we discussed suggests that the fiscal channel can generate the main stylized facts associated with these reforms: an expansion with prominent consumption booms, a deterioration of the current account, and an increase in the real wage rate and in the relative price of non-tradables.

The model we explored also rationalizes one puzzling feature of many reforms: the fact that an economic expansion takes place at the same time that tax rates are increased. The reform led to a tax increase that is smaller than the one that would eventually take place if the economy continued in the non-reform state. Furthermore, the reform contains the growth in government spending. As a result the private sector experiences a positive wealth effect that leads to an increase in consumption and to an economic expansion.

The economic events that follow the adoption of a fixed exchange rate regime have often been attributed to irrationality or to lack of foresight on the part of the private sector. The observed consumption booms and real appreciations are too large to be simply the result of a disinflation process. It is thus encouraging that a simple fiscal story can contribute to rationalizing these events. However, there are still many questions to be investigated about the potential role of the fiscal channel.

First, the behavior of fiscal variables during exchange rate episodes needs to be examined more closely. One of the symptoms that suggests that fiscal policy is less profligate after reform is that the government's deficit tends 
to decline. This decline in the deficit that tends to follow a peg may not be the result of an effective fiscal reform. Instead, it may simply reflect the cyclical behavior of the deficit: the expansion that tends to follow the reform automatically increases tax revenue, while reducing cyclically-sensitive expenditures such as unemployment benefits.

Second, if the fiscal channel is an important force, we would expect to see its effects in episodes of fiscal reform that are not accompanied by monetary reforms. Empirical evidence on these episodes would clearly be helpful in evaluating the plausibility of the fiscal mechanism that we describe.

Third, we assumed that the exchange rate peg provides a strong incentive to undertake fiscal reforms and to maintain those reforms. If, in the eve of an election the economy is in a recession and the government is tempted to increase expenditures, this temptation might be easier to resist under fixed exchange rates: a signal of loose fiscal policy might trigger a speculative attack that may cost the government the election. More theoretical work is, however, necessary to explore formally these credibility links. ${ }^{15}$

Fourth, we only examined permanent reforms. When reforms can be reversed there can be important credibility effects. Preliminary work on this issue suggests that the introduction of imperfect credibility preserves the main elements of the credible reforms described in this paper, at the same time it suggests an explanation for the high volatility that characterizes economies that undergo reforms. With imperfect credibility any shock to terms of trade, world interest rates, etc. carries with it two types of effects: the direct effect of the shock, and the indirect effect associated with the change in the probability that the reform will be carried out. This can greatly enhance the response of the economy to exogenous shocks.

Finally, we assumed that the adoption of fixed exchange rates and the associated policy changes were an exogenous event. In practice, the timing and the character of the reforms is often shaped by the interplay of political forces. These same political aspects are also often responsible for the abandonment of the reforms. In particular, lobbying activity on the part of the tradables industry often influences the collapse of the exchange rate regime.

\footnotetext{
${ }^{15} \mathrm{An}$ interesting recent example of the links between exchange rate policy and fiscal policy is provided by the U.K.'s withdrawal from the exchange rate mechanism of the EMS in 1992. One prime motivation for this withdrawal was the desire to pursue expansionary fiscal policy. The budget deficit expressed as percentage of GDP was -1.3 in 1990 and -2.7 in 1991 but widened to -6.2 in 1992 and to -8.8 in 1993 .
} 
Work on the political economy aspects of reforms is another dimension along which our understanding of the complexities of macroeconomic reforms can be improved.

\section{References}

[1] Ades, Alberto, Miguel Kiguel and Nissan Liviathan "Exchange-RateBased Stabilization: Tales from Europe and Latin America," World Bank working paper, 1993.

[2] Alesina, Alberto "Politics and Business Cycles in Industrial Democracies," Economic Policy, 8: 55-98, 1989.

[3] Alesina, Alberto, Gerard Cohen and Nouriel Roubini, "Macroeconomic Policy and Elections in OECD Democracies," Economics and Politics, 4: 1-30, 1992.

[4] Aukrust, O. "Inflation in an Open Economy: A Norwegian Model," in L. Krause and W. Salant, eds. Worldwide Inflation, The Brookings Institution, Washington, D.C., 1977.

[5] Bacchetta, Philippe, "Spain and The Real Exchange Rate Problem," in C. Johnson and S. Collignon (eds), Monetary Economics in Europe Causes of the EMS Crisis, Pinter Publishers, 1994.

[6] Bacchetta, Philippe, "The Lessons from Fiscal Reform in Democratic Spain," in K. Mizsei (ed.), Developing Public Finance in Emerging Market Economies, Institute for EastWest Studies, 183-202, 1994.

[7] Backus, David and John Driffill "Credible Disinflation in Closed and Open Economies," Ricerche Economiche, 41: 326-40, 1987.

[8] Backus, David, Patrick Kehoe and Finn Kydland, "International Real Business Cycles," Journal of Political Economy, 101 (August 1992), 745755 .

[9] Baxter, Marianne and Mario Crucini, "Explaining Saving/Investment Correlations," American Economic Review, 83: 416-436, 1993. 
[10] Bover, Olympia "An Empirical Model of House Prices in Spain," mimeo, Bank of Spain, 1992.

[11] Bover, Olympia and Angel Estrada "Durable Consumption and House Purchases: Evidence from Spanish Panel Data," mimeo, Bank of Spain, 1994.

[12] Bruno, Michael "The Two-Sector Open Economy and the Real Exchange Rate," American Economic Review: 66, 566-577, 1976.

[13] Calvo, Guillermo, "Staggered Prices in an Utility-Maximizing Framework," Journal of Monetary Economics, 12: 383-98, 1983.

[14] Calvo, Guillermo "Temporary Stabilization: Predetermined Exchange Rates," Journal of Political Economy, 94: 1319-29, 1986.

[15] Calvo, Guillermo and Carlos Vegh "Exchange-Rate Based Stabilization under Imperfect Credibility," in Helmut Frisch and Andreas Worgotter Open Economy Macroeconomics, 3-28, MacMillan Press, 1993.

[16] Cardia, Emanuela, "The Dynamics of a Small Open Economy in Response to Monetary, Fiscal and Productivity Shocks," Journal of Monetary Economics, 28 (December 1991), 411-134.

[17] Copelman, Martina "The Role of Credit in Post-Stabilization Booms," mimeo, M.I.T, 1994.

[18] Corbo, Vittorio, "International Prices, Wages and Inflation in an Open Economy: A Chilean Model," Review of Economics and Statistics, 564$573,1985$.

[19] Correia, Isabel, Joao Neves and Sergio Rebelo, "Business Cycles in a Small Open Economy," European Economic Review, 39: 1089-1113, 1995.

[20] De Gregorio, Jose, Alberto Giovaninni and Thomas Krueger, "The Behavior of Non-Tradable Goods Prices in Europe: Evidence and Interpretation," mimeo, International Monetary Fund, 1993.

[21] Dornbusch, R. "Real Exchange Rates and Macroeconomics: A Selective Survey," Scandinavian Journal of Economics, 91, 401-432, 1989. 
[22] Drazen, Allan and Elhanan Helpman, "Stabilization with Exchange Rate Management under Uncertainty," in E. Helpman, A. Razin and E. Sadka, eds., Economic Effects of the Government Budget, MIT Press, Cambridge, MA, 310-27, 1988.

[23] Drazen, Allan and Elhanan Helpman, "Inflationary Consequences of Anticipated Macroeconomic Policies," Review of Economic Studies, 57: 147-64, 1990.

[24] Erceg, Christopher and Andrew Levin "Productivity, Capital Flows and Real Exchange Rate Determination: Lessons from Argentina," mimeo, Board of Governors of the Federal Reserve System, 1994.

[25] Fernandez, Roque, "What Have Populists Learned From Hyperinflation?," in Dornbusch and Edwards (1991), Macroeconomics of Populism in Latin America, Chicago University Press.

[26] Finn, Mary, "On Savings and Investment Dynamics in a Small Open Economy," Journal of International Economics, 29 (1990), 1-21.

[27] Fischer, Stanley "Contracts, Credibility and Disinflation," in Stanley Fischer (ed.) Indexing, Inflation and Economic Policy, MIT Press, Cambridge, MA 1986.

[28] Fischer, Stanley "Real Balances, the Exchange Rate, and Indexation: Real Variables in Disinflation," Quarterly Journal of Economics, 27-49, 1988.

[29] Frenkel, J. and Assaf Razin, Fiscal Policies and the World Economy, MIT Press, Cambridge, 1987.

[30] Froot, Kenneth and Kenneth Rogoff, "The EMS, the EMU and the Transition to a Common Currency," NBER Macroeconomics Annual 1991, MIT Press 1992.

[31] Gottfries, Nils "Market Share and Pricing Behavior in the Tradables Industry: A Study of Swedish Manufacturing Exports, mimeo, Institute for International Economic Studies, 1991. 
[32] Greenwood, J. "Non-Traded Goods, the Trade Balance, and the Balance of Payments," Canadian Journal of Economics, 17, 806-823, 1984.

[33] Helpman, Elhanan and Assaf Razin, "Exchange Rate Management: Intertemporal Tradeoffs," American Economic Review, 77: 107-23, 1987.

[34] King, Robert, Charles Plosser and Sergio Rebelo, "Production, Growth and Business Cycles I: The Basic Neoclassical Model," Journal of Monetary Economics, 21, 195-232, 1988.

[35] Kiguel, Miguel and Nissan Liviatan "The Business Cycle Associated with Exchange Rate-Based Stabilizations," The World Bank Economic Review, 6: 279-305, 1988.

[36] Krugman, Paul "A Model of Balance-of-Payments Crises," Journal of Money, Credit and Banking, 11:3, 311-325, August 1979.

[37] Larrain, Felipe and Patricio Meller "The Socialist Populist Chilean Experience, 1970-1973," in Dornbusch and Edwards (1991), Macroeconomics of Populism in Latin America, Chicago University Press.

[38] Lindbeck, Assar "Imported and Structural Inflation and Aggregate Demand: the Scandinavian Model Reconstructed," in Assar Lindbeck (ed.) Inflation and Employment in Open Economies, North-Holland, 1979.

[39] Lundvik, Petter "Business Cycles in a Small Open Economy: Sweden 1871-1987," mimeo, Stockholm University, 1992.

[40] Mendoza, Enrique, "Real Business Cycles in a Small Open Economy," American Economic Review, 81 (September 1991), 797-818.

[41] Miller, Marcus and Alan Sutherland "Contracts, Credibility and Common Knowledge: Their Influence on Inflation Convergence," in Torres and Giavazzi (eds.) Adjustment and Growth in the European Monetary Union, Cambridge University Press, 1993.

[42] Obstfeld, Maurice "Macroeconomic Policy, Exchange Rate Dynamics and Optimal Asset Accumulation," Journal of Political Economy, 89, 1142-1161, 1981. 
[43] Persson, Torsten and Lars Svensson, "Current Account Dynamics and the Terms of Trade: The Harberger-Laursen-Metzler Effect Two Generations Latter," Journal of Political Economy, 93, 43-65, 1985.

[44] Razin, Assaf "Capital Movements, Intersectoral Resource Shifts and the Trade Balance," European Economic Review, 26, 135-152, 1984.

[45] Rebelo, Sergio "Inflation in Fixed Exchange Rate Regimes: The Recent Portuguese Experience," in Torres and Giavazzi (eds.) Adjustment and Growth in the European Monetary Union, Cambridge University Press, 1993.

[46] Rebelo, Sergio and Carlos Vegh "Exchange-Rate-Based Stabilizations: An Analysis of Competing Theories, "NBER Macroeconomics Annual 1995, 125-174.

[47] Reinhart, Carmen and Carlos Vegh "Nominal Interest Rates, Consumption Booms and Lack of Credibility: A Quantitative Examination," mimeo, IMF, 1992.

[48] Rodriguez, Carlos "The Argentine Stabilization Plan of December 20th," World Development, 10: 801-11, 1982.

[49] Roldos, Jorge E. "On Credible Disinflation," International Monetary Fund working paper, 1993.

[50] Roldos, Jorge E. "Supply Side Effects of Disinflation Process," International Monetary Fund working paper, 1994.

[51] Sargent, Thomas "The Ends of Four Big Inflations," in Robert Hall (ed.) Inflation: Causes and Effects, Chicago University Press, 1982.

[52] Sargent, Thomas, and Neil Wallace, "Some Unpleasant Monetarist Arithmetic," Federal Reserve Bank of Minneapolis Quarterly Review 5:117, 1981.

[53] Stockman, Alan and Linda Tesar, "Tastes and Technology in a TwoCountry Model of Business Cycles: Explaining International Comovements," mimeo, November 1990. 
[54] Sturzenegger, Frederico "Description of a Populist Experience: Argentina, 1973-1976," in Dornbusch and Edwards (1991), Macroeconomics of Populism in Latin America, Chicago University Press.

[55] Svensson, Lars and Assaf Razin, "The Terms of Trade and the Current Account: The Harberger-Laursen-Metzler Effect," Journal of Political Economy, 91, 97-125, 1983.

[56] Taylor, John "Union Wage Settlements During a Disinflation," American Economic Review, 73: 981-93, 1983.

[57] Uribe, Martin "Exchange-Rate-Based Inflation Stabilization: The Initial Real Effects of Credible Plans," mimeo, University of Chicago, October 1993.

[58] Vegh, Carlos "Stopping High Inflation: An Analytical Overview," IMF Staff Papers 39: 626-95, 1992. 
TABLE 1

Baseline Parameterization

\begin{tabular}{|l|l|}
\hline Parameters & Benchmark Value \\
\hline \multicolumn{2}{|l|}{} \\
\hline International Real Interest Rate $\left(r^{*}\right)$ & 0.01 \\
\hline Discount Factor $(\beta)$ & 0.99 \\
\hline Rate of Devaluation $(\varepsilon)$ & 0.46 \\
\hline Depreciation Rate $(\delta)$ & 0.025 \\
\hline Labor Share, Tradables Sector $(\alpha)$ & 0.48 \\
\hline Labor Share, Non-Tradables Sector $(\eta)$ & 0.63 \\
\hline Elasticity of Intertemporal Substitution $(\sigma)$ & 0.20 \\
\hline Elasticity Parameters, Momentary Utility $(\nu)$ & 3.00 \\
\hline Level Parameter, Momentary Utility $(\psi)$ & 22.75 \\
\hline Level Parameter, Tradables Production $\left(Z^{T}\right)$ & 1.00 \\
\hline Level Parameter, Non-Tradables Production $\left(Z^{N T}\right)$ & 4.76 \\
\hline Level Parameter, Shopping Technology $\left(Z^{S}\right)$ & 1.00 \\
\hline Level of Net Foreign Assets $(a)$ & -6.81 \\
\hline Adjustment Cost Elasticity $(\zeta)$ & 0.067 \\
\hline Government Expenditures in Tradables $\left(G^{T}\right)$ & 0.25 \\
\hline Government Expenditures in Non-Tradables $\left(G^{N T}\right)$ & 0.51 \\
\hline Tax Rate on Output $(\tau)$ & 0.10 \\
\hline
\end{tabular}

Note: Each period is meant to represent one quarter. 
Figure 1: The Effects of an Increase in Net Foreign Assets
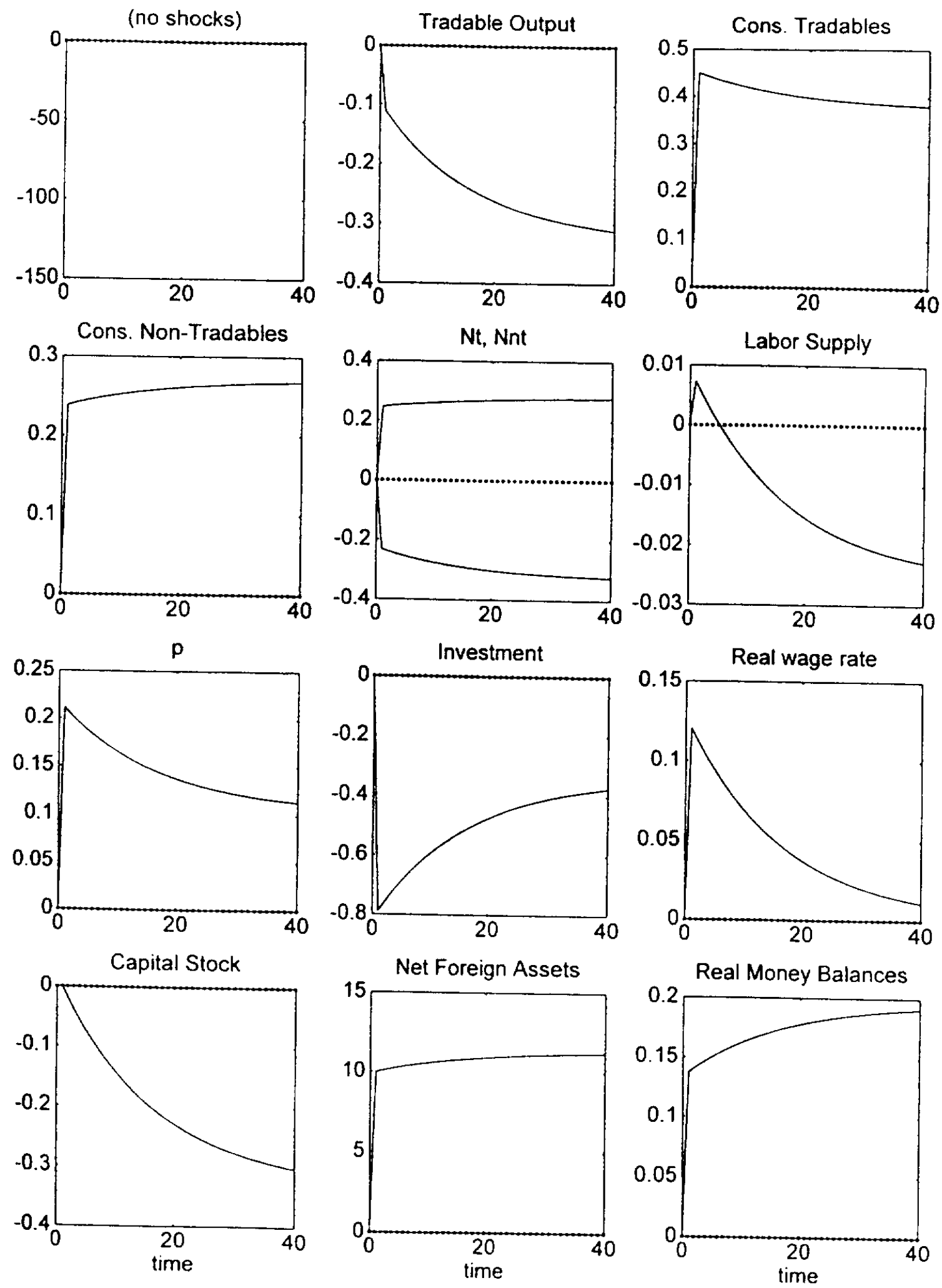


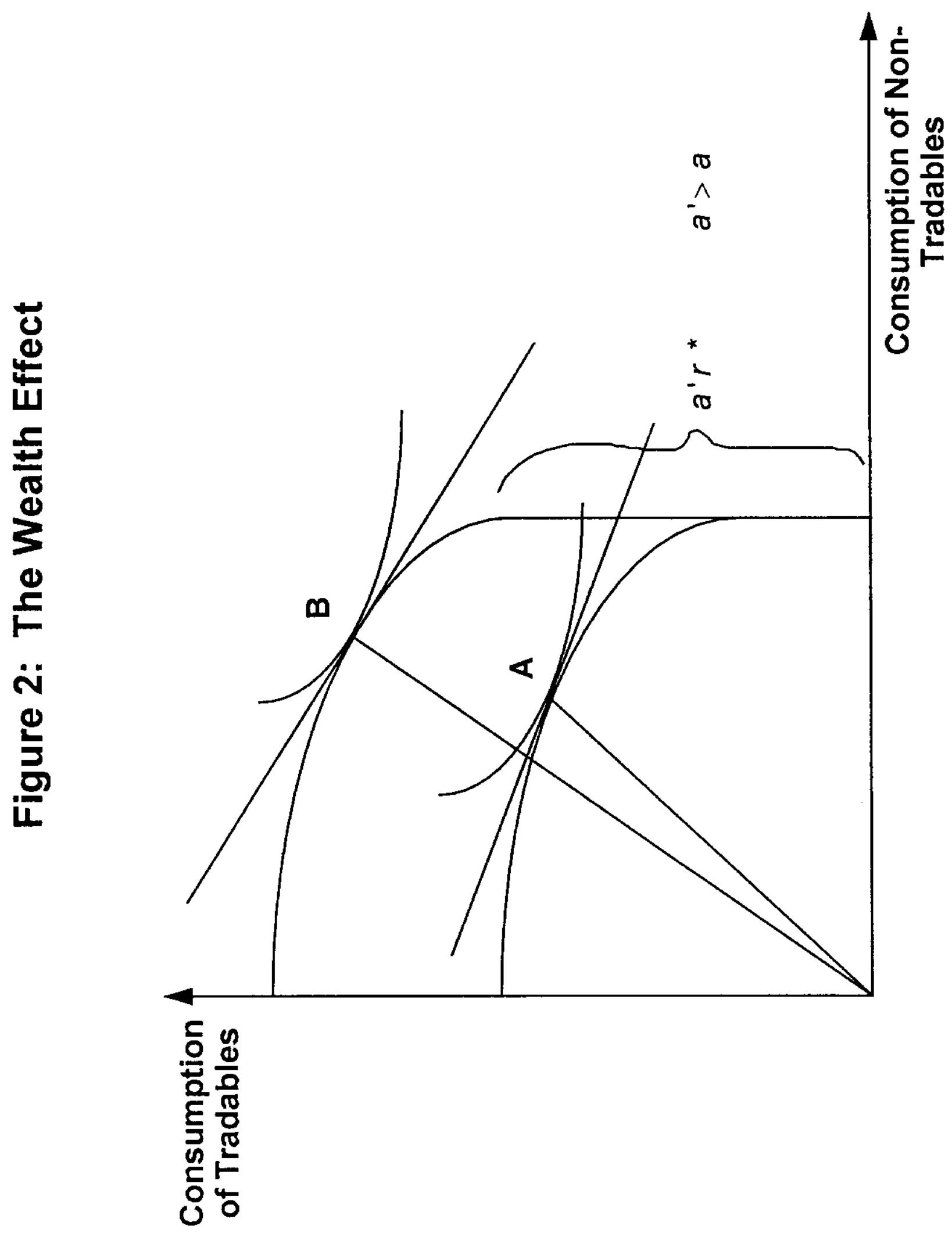


Figure 3: The Expected Path of Government Expenditures
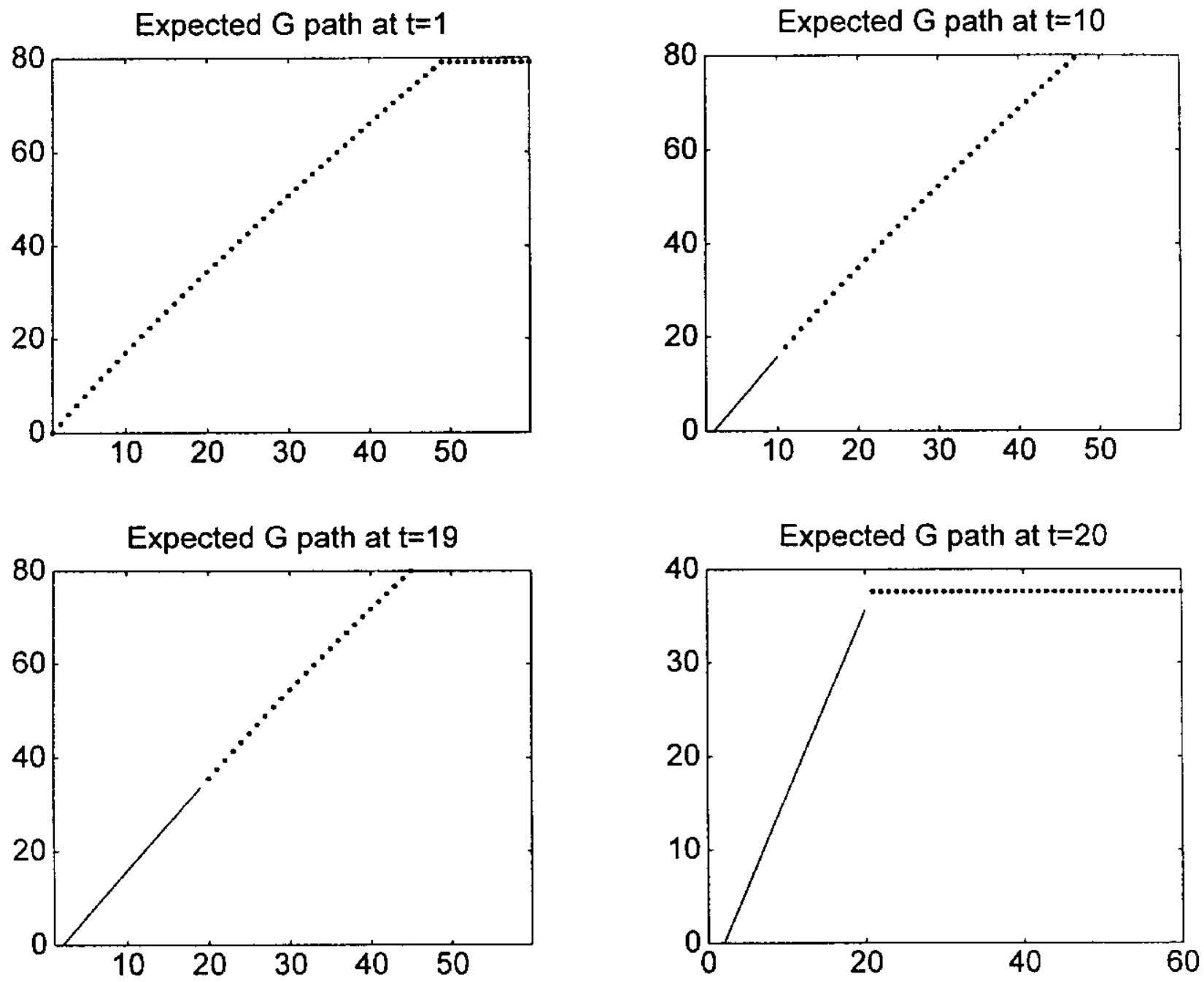
Figure 4: Experiment 1-A Stabilization of Government Spending
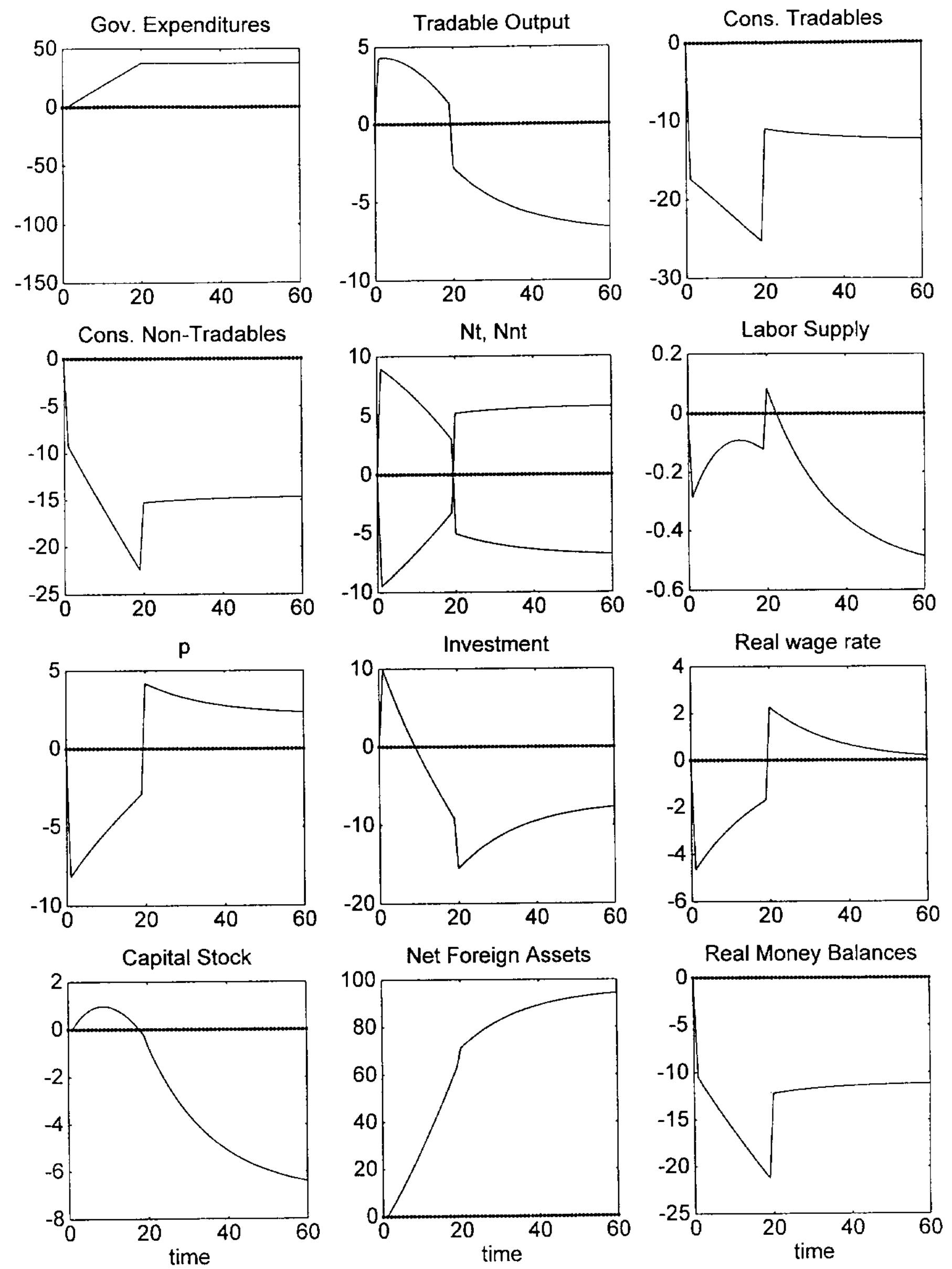
Figure 5: Expected Path of Output Tax Rate
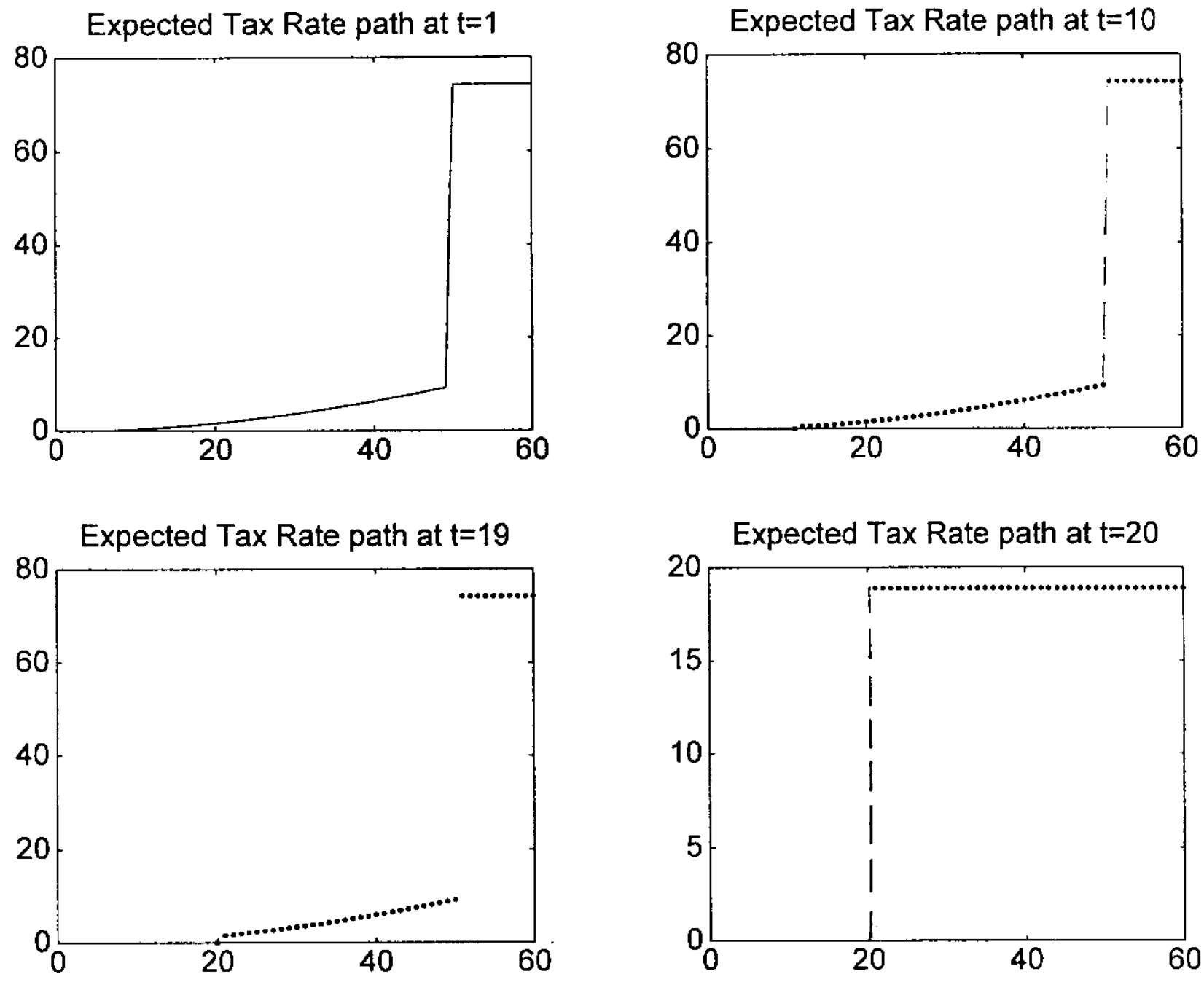
Figure 6: Experiment 2-A Stabilization of Government Spending with a Rise in Output Taxes
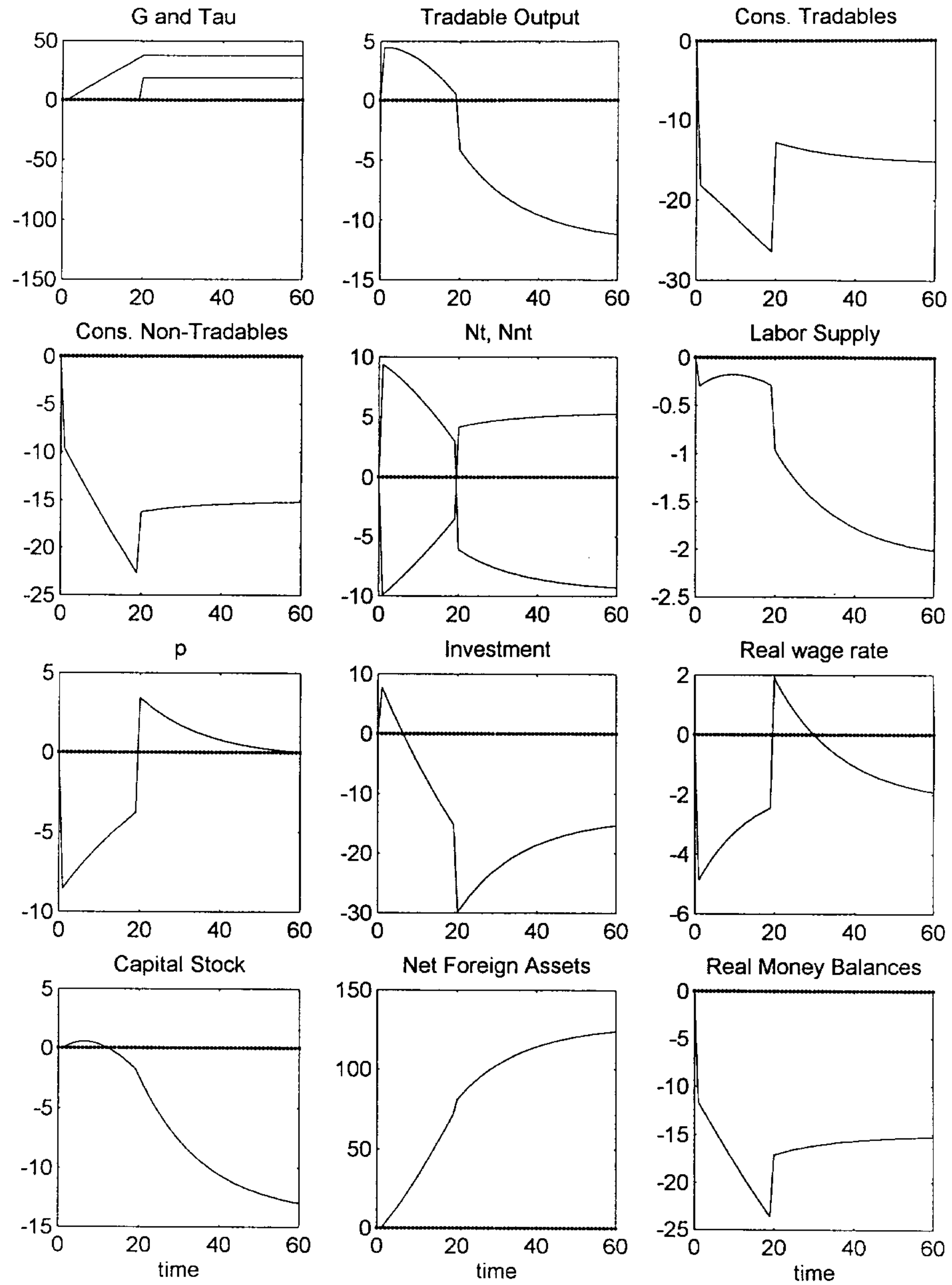
Figure 7: Experiment 3-Incorporating the Effects of Disinflation
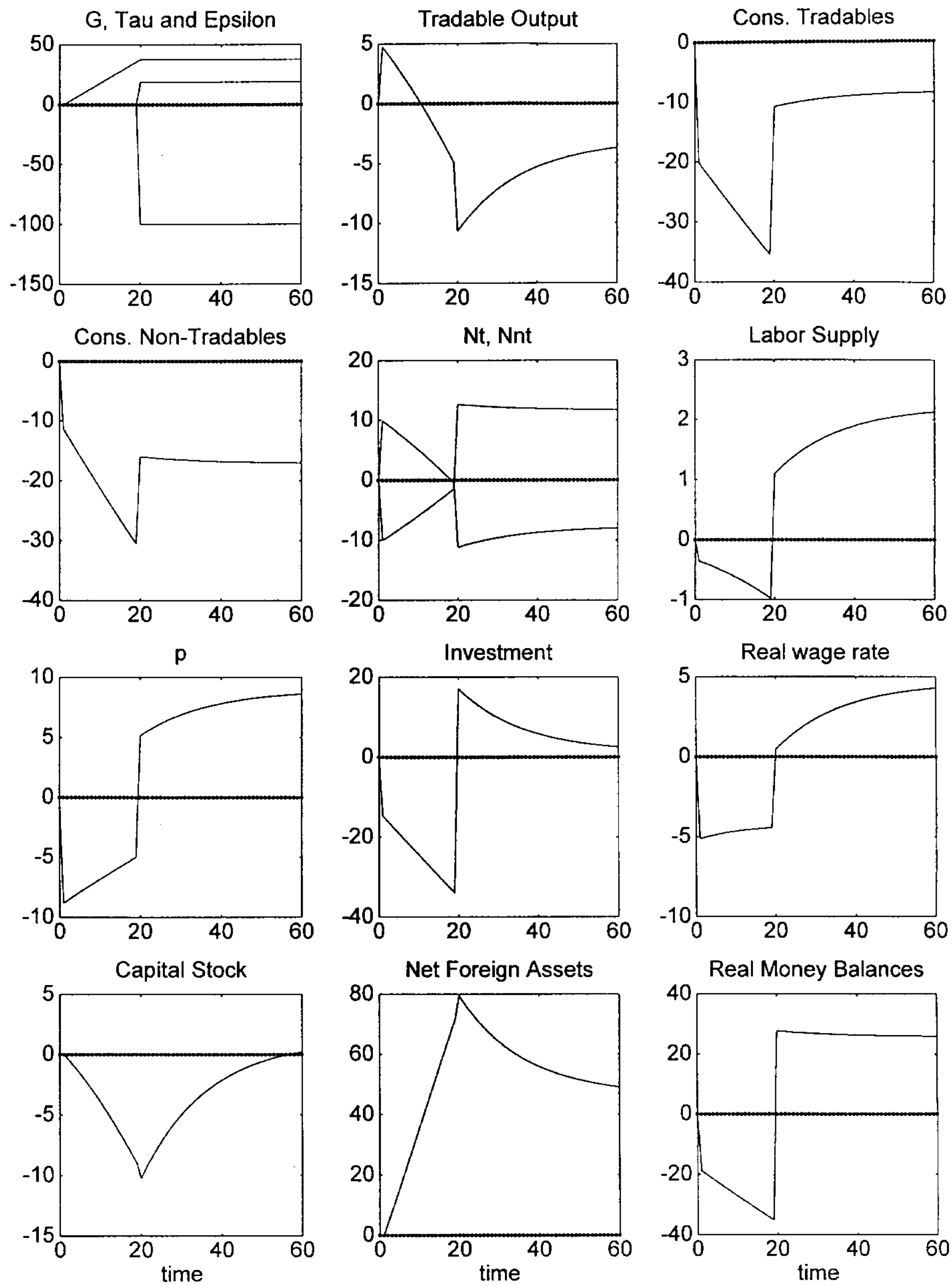